\title{
Spatio-temporal distribution of slope failures in the Western Ghats of Kerala, India
}

\author{
S. Sreekumar \& A. Aslam \\ Department of Geology and Environmental Science, \\ Christ College, India
}

\begin{abstract}
The Western Ghats, the main peninsular hill range in India, is prone to several types of slope failures, of which debris flows are most common. Kerala has a total area of $38863 \mathrm{~km}^{2}$ and $47 \%$ of the state lies on the western slopes of the Western Ghats. The average annual rainfall in the highranges is $500 \mathrm{~cm}$. The state has a population density of 819 per $\mathrm{km}^{2}$. The volumes of hectic anthropogenic activities are bringing the slopes to the geotechnical threshold of failure. The field investigation carried out indicates that the natural instabilities are accentuated by anthropogenic factors, such as deforestation, contour terracing, obstruction of the natural drainage, artificial loading of water on the steep slopes and cultivation of shallow rooted crops. A strong relationship between slope failure and rainfall could be established in all paleoslide events. The rainfall induced pore pressure acted as the trigger force for the onset of debris flow, landslide and slump along the slopes, which were already at the threshold of failure. It is concluded that it is not the rainfall on the day of occurrence of the incidence that counts, but rainfall received a few days before the event is more decisive in causing landslides. The failures are observed in hills with gradients $>20^{\circ}$, both in highland and midland regions. This paper presents the cause and mechanism of ten major landslide events in the state.
\end{abstract}

Keywords: landslide, Western Ghats, Kerala, land use, debris flow, slump, rainfall, pore pressure.

\section{Introduction}

Slope failures are among the major geohazards that effect large parts of India, especially in the Himalayas, which forms the most prominent mountain range 
bordering India on the northern side and the Western Ghats on the southwestern parts. The Himalayas are a tectonically active, comparatively young mountain system with weak and fragile litho units. On the other hand, the Western Ghats is composed of peninsular gneiss, granite and other crystalline rocks of Precambrian age. The slope failures in the Western Ghats are of smaller dimension and with shallow depth compared to that of the great Himalayas. The Western Ghats extends over $1400 \mathrm{~km}$ and run parallel to the west coast of India at a distance of about $40 \mathrm{~km}$ inland from the sea shore. Numerous catastrophic landslides have occurred in the southern Western Ghats, along the steep slopes overlooking the Konkan coast. The state of Kerala comprises of the parts of the southern most segments of the Western Ghats with a total area of $38863 \mathrm{~km}^{2}$. According to the Census of India [1], 47\% of the state lies on the western slopes of the Western Ghats and has a population density of 819 per $\mathrm{km}^{2}$. The average annual rainfall in the highranges is $500 \mathrm{~cm}$. Kumar [2] found that even though the state once supported a vast area of forest, over the 30 year period from 1940 to 1970 , there was a steep drop in the forest area with cumulative loss of publically managed forest averaging 5000 ha annually. Landuse changes in Kerala were unprecedented during the past half century. The substantial decline in the forest area and an increase in rubber plantations have led to frequent flashfloods, soil erosion and landslides, causing serious ecological and environmental problems. As the forests have declined at an alarming rate, especially in the upland watershed of Kerala with its rolling topography, copious rainfall and unscientific land use practices have caused land degradation, has continued unabated, leading to frequent landslide disasters. According to Sekhar et al. [3], the slope instability in Kearla Western Ghats is accelerated by anthropogenic disturbances.

The Western Ghats of the Kerala region experience several types of mass movements, such as debris flow, landslides, slump and rock fall. The region has been categorized by Thampi et al. [4] and Sreekumar [5] as a Highly Hazardous Zone for mass movement. The most prevalent, recurring and most disastrous type of mass movement noted in Kerala is 'debris flows'. The causative factors and triggering mechanisms are site specific. The studies by Simoni et al. [6] indicated that the pore water pressure is considered as an important factor that triggers landslides. Melelli and Tharmalli [7] concluded that initiation of the debris flows originates in topographic depressions depicted by concave contours called hollows. A detailed analysis of ten major slope failures that have occurred during the past two decades in different geographical areas has been carried out and four case studies are discussed in detail.

\section{Study area}

Major and typical slope failures, which are spatially distributed from South to North in the Kerala Western Ghats from 1993 to 2009, are studied in detail (fig. 1). The locations from south to north are Amboori in the Trivandrum district, Vadavathoor in the Kottayam district, Pullupara, Ninnumullipara, Govt. College, Munnar and Anthoniar Colony, Munnar in the Idukki district, Akamala 


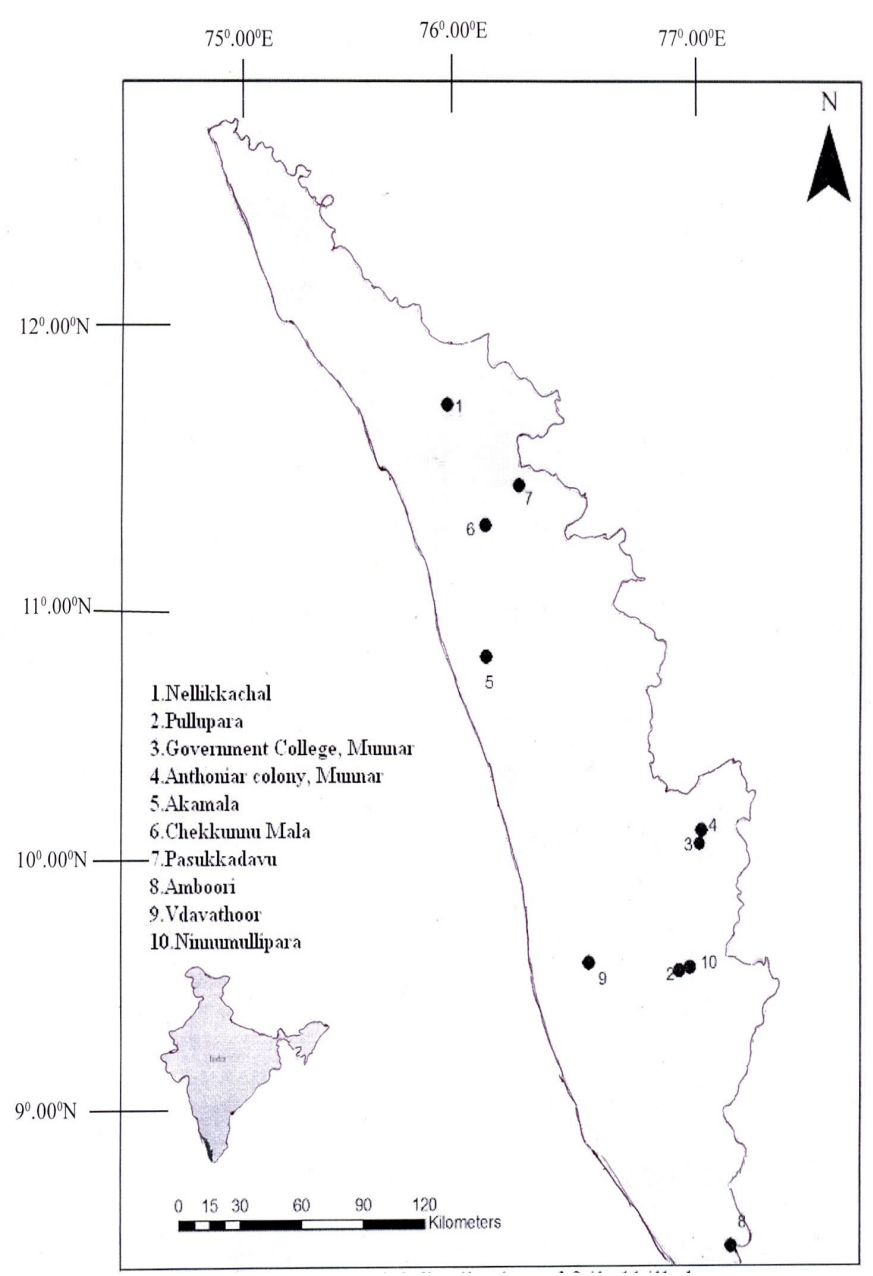

Figure 1: $\quad$ Spatial distribution of failed hill slopes.

in the Thrissur district, Chekkunnu Mala in the Malappuram district, Pasukkadavu in the Kozhikkode district and Nellikkachal in the Kannur district.

\section{Methodology}

The evaluation is based on the systematic field work carried out immediately after the occurrence of disasters as part of doctoral work and research projects. The important data regarding slope, lithology, attitude and spacing of discontinuities are measured in the field. Rainfall data available at the nearest rain gauge stations was collected. Samples of the weakest lithounits were collected from each location and the material properties, such as Cohesion (C), Friction angle $(\Phi)$ and Void Index (VI), were determined in geotechnical 
laboratories. The failure surfaces were identified in the field. The orientation of failure planes and all the dominant joint planes were marked in the stereo-plot. The general slope of the hill and the angle of internal friction of the weakest rock type were also incorporated. The geometric analysis of the slopes followed by Hoek and Bray [8] was used to identify the type of failure that had occurred along the profile and also to examine whether the vulnerability of the profile to landslide still exists.

\section{Result and discussion}

The type of failure, date of event, lithology, type of vegetation and the causative factors of the ten failed slopes are presented in table 1.

\subsection{Ninumullipara, Wedge Failure (1993)}

The slope process in this location is classified under wedge failure. The slide occurred along the road cut cliff, which is very steep and overhangs the road in places. The valley side is deep with a high gradient and a very steep cliff with perennial water seepage. The vegetation is sparse on the cliff. The road is at an elevation of $1000 \mathrm{~m}$ above MSL. The relative relief in this region is $450 \mathrm{~m}$. The important rock type forming the slopes is granitic gneiss, charnockite and pyroxene granulite. Pegmatite veins of width 2 to $10 \mathrm{~cm}$ also occur. The rocks are weathered to differing degrees. The rock is well jointed and gaping of joints is greater than $1 \mathrm{~cm}$. The wedge failure occurred in the road cut cliff with a height of $7.6 \mathrm{~m}$. The general slope is $75^{\circ} \mathrm{N} 210$ and cliff slope $84^{\circ} \mathrm{N} 210$. The wedge of rock block has moved along the line of intersection of the two slide planes with attitudes $80^{\circ} \mathrm{N} 280(\mathrm{~J} 1)$ and $64^{\circ} \mathrm{N} 170(\mathrm{~J} 2)$. The friction angle for the granitic gneiss is $40^{\circ}$. The orientation of the joint planes that confined the slide debris and the friction angle of the rock are illustrated in the equal area projection (fig. 2). The methodology followed by Hoek and Bray [8] was carried out to understand the mechanism of the slope failure. Water seeps through the discontinuities and the presence of water along these joints further reduced the factor of safety. The impact of slide debris caused the massive destruction of the road that snapped the main communication artery connecting the Kerala state and Tamil Nadu for a couple of days.

\subsection{Pasukkadavu, debris flow (2004)}

The Pasukkadavu debris flow that occurred on August 04, 2004 was the most disastrous one, claiming ten lives and destroying three houses. Pasukkadavu hill slope profile has a maximum elevation of $775 \mathrm{~m}$ and lowest elevation of $300 \mathrm{~m}$ from the mean sea level. Granitic gneiss forms the chief rock type of the area with an angle of internal friction of $34^{\circ}$. The scar of the slide has a crown with width $5 \mathrm{~m}$ and depth $1 \mathrm{~m}$. Further downwards the width increases up to $30 \mathrm{~m}$ but becomes much shallower. The overburden consists of highly weathered rocks, boulders, laterites and colluvial debris. The thickness of the overburden 
Table 1: Locations, type of failure, date of event, lithology and causative factors.

\begin{tabular}{|c|c|c|c|c|c|}
\hline $\begin{array}{r}\text { Sl } \\
\text { No }\end{array}$ & Locations & $\begin{array}{l}\text { Type of } \\
\text { failure }\end{array}$ & $\begin{array}{c}\text { Date of } \\
\text { event }\end{array}$ & Lithology & $\begin{array}{l}\text { Catalystic } \\
\text { factors }\end{array}$ \\
\hline 1 & Nellikachal & $\begin{array}{l}\text { Debris } \\
\text { flow }\end{array}$ & 14 July 2009 & $\begin{array}{c}\text { Granitic } \\
\text { Gneiss and } \\
\text { Laterite }\end{array}$ & $\begin{array}{c}\text { Unscientific } \\
\text { road } \\
\text { construction }\end{array}$ \\
\hline 2 & Pullupara & $\begin{array}{c}\text { Debris } \\
\text { flow }\end{array}$ & $\begin{array}{c}6 \text { September } \\
2008\end{array}$ & $\begin{array}{l}\text { Charnockite } \\
\text { (weathered) } \\
\text { and Laterite }\end{array}$ & $\begin{array}{l}\text { Only natural } \\
\text { factors }\end{array}$ \\
\hline 3 & $\begin{array}{c}\text { Govt. } \\
\text { College, } \\
\text { Munnar }\end{array}$ & Slump & 25 July 2005 & $\begin{array}{c}\text { Red } \\
\text { Laterite }\end{array}$ & $\begin{array}{c}\text { Toe cutting } \\
\text { and } \\
\text { modification } \\
\text { of natural } \\
\text { drain }\end{array}$ \\
\hline 4 & $\begin{array}{l}\text { Anthoniar } \\
\text { Colony, } \\
\text { Munnar }\end{array}$ & Slump & 25 July 2005 & $\begin{array}{c}\text { Laterite, } \\
\text { Granitic } \\
\text { Gneiss } \\
\text { (weathered) }\end{array}$ & $\begin{array}{c}\text { Slope } \\
\text { Modification }\end{array}$ \\
\hline 5 & Akamala & $\begin{array}{l}\text { Debris } \\
\text { flow }\end{array}$ & 5 June 2004 & $\begin{array}{c}\text { Gneissic } \\
\text { charnockite, } \\
\text { laterite }\end{array}$ & deforestation \\
\hline 6 & $\begin{array}{c}\text { Chekkunnu } \\
\text { Mala }\end{array}$ & $\begin{array}{l}\text { Debris } \\
\text { flow }\end{array}$ & 17 July 2004 & $\begin{array}{l}\text { Micaceous } \\
\text { rich gneiss } \\
\text { and laterite }\end{array}$ & $\begin{array}{c}\text { Improper } \\
\text { slope } \\
\text { modification }\end{array}$ \\
\hline 7 & Pasukkadavu & $\begin{array}{l}\text { Debris } \\
\text { flow }\end{array}$ & $\begin{array}{l}4 \text { August } \\
2004\end{array}$ & $\begin{array}{c}\text { Granitic } \\
\text { gneiss } \\
\text { (weathered) }\end{array}$ & $\begin{array}{l}\text { Artificial } \\
\text { loading of } \\
\text { water on } \\
\text { slopes }\end{array}$ \\
\hline 8 & Amboori & $\begin{array}{l}\text { Debris } \\
\text { flow }\end{array}$ & $\begin{array}{c}9 \text { November } \\
2001\end{array}$ & $\begin{array}{c}\text { Biotite } \\
\text { gneiss and } \\
\text { laterite }\end{array}$ & $\begin{array}{c}\text { Blockage of } \\
\text { water } \\
\text { seepages }\end{array}$ \\
\hline 9 & Vadavathoor & Slump & 10 July 1995 & Laterite & $\begin{array}{c}\text { Toe cutting } \\
\text { and steep cut } \\
\text { slope }\end{array}$ \\
\hline 10 & $\begin{array}{c}\text { Ninnu- } \\
\text { mullipara }\end{array}$ & $\begin{array}{l}\text { Wedge } \\
\text { failure }\end{array}$ & 31 July 1993 & $\begin{array}{c}\text { Granitic } \\
\text { gneiss, } \\
\text { charnockite }\end{array}$ & $\begin{array}{l}\text { Only natural } \\
\text { factors }\end{array}$ \\
\hline
\end{tabular}

ranges from 1 to $3.1 \mathrm{~m}$. The terrain is characterized by isolated rocky tops with near vertical slopes. The general downward slope of the profile is $48^{\circ}$ towards East. The entire hill slope is under cultivation, barring the rocky tip. The vegetation patterns include mixed crops containing plantain, pepper, coconut, and jack fruit tree. Four major joints traverse the profile with gaping ranging from 1 to $2 \mathrm{~cm}$. The major joints have attitudes of $51^{\circ} \mathrm{N}(\mathrm{J} 1), 32^{\circ} \mathrm{N} 90 \mathrm{E}(\mathrm{J} 2)$, $22^{\circ} \mathrm{N} 90 \mathrm{E}(\mathrm{J} 3)$ and $80^{\circ} \mathrm{N} 90 \mathrm{E}(\mathrm{J} 4)$. 


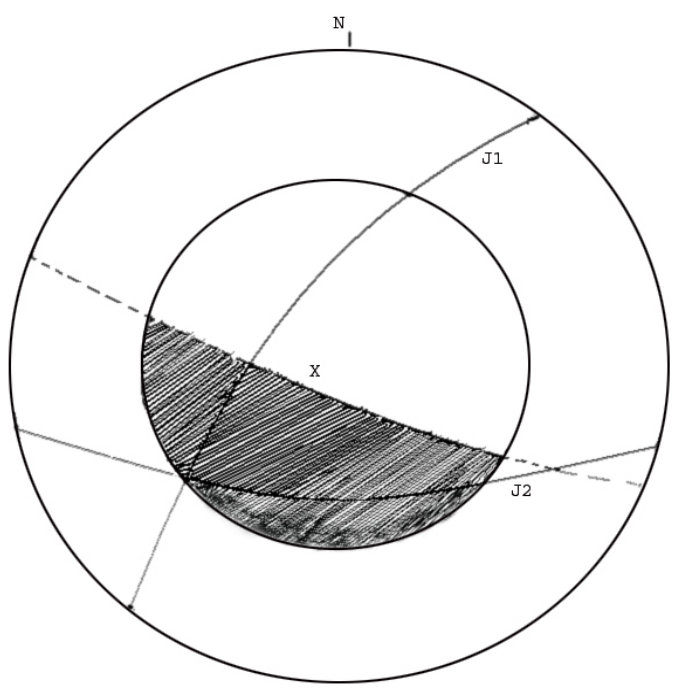

Figure 2: The orientation of the joint planes that confined the slide debris and the friction angle of the rock are illustrated in the equal area projection.

The geometrical analysis indicates that the failure that occurred is a type of plane failure. The joint along which the slide occurs $\left(32^{\circ} \mathrm{N} 90 \mathrm{E}\right)$ is oriented parallel to the general slope (fig. 3).

The angle of internal friction decreases when water infiltrates into joint planes of rocks. The blockade of water seepages along the joints for rainwater harvesting purposes has created excess pore pressure across the weak planes of weathered rocks and it triggered the slope failure.

\subsection{Vadavathoor, slump (1995)}

Slope failure in the lateritic profile at Vadavathoor is a typical slump that occurred on July 10, 1995. Agricultural land had been damaged and a flour mill was partially destructed consequent to the slump. The maximum height of the cliff is $15 \mathrm{~m}$ and the slope of the cliff is $80^{\circ} \mathrm{N} 50$. Lithologically it is a lateritic profile with the occasional zone of weakly lateritised crystalline rocks. A minor exposure of granitic gneiss is observed at the base of the cliff. The cohesive strength and friction angle of the laterite sample from the weakest zone is 0.43 $\mathrm{kg} \backslash \mathrm{sqcm}$ and $10^{\circ}$, respectively. The factor of safety calculated before the incidence by the Swedish method of Fellenius [9] under dry condition was 1.03. Water infiltrated through the porous upper soil and the lateritic zone below it. The zone below the laterite is saprolite, which is less porous and further down lies weathered and fresh crystalline rock. The vertical flow of infiltrating water was prevented because of the relatively less porous rock types. A spring resulted 


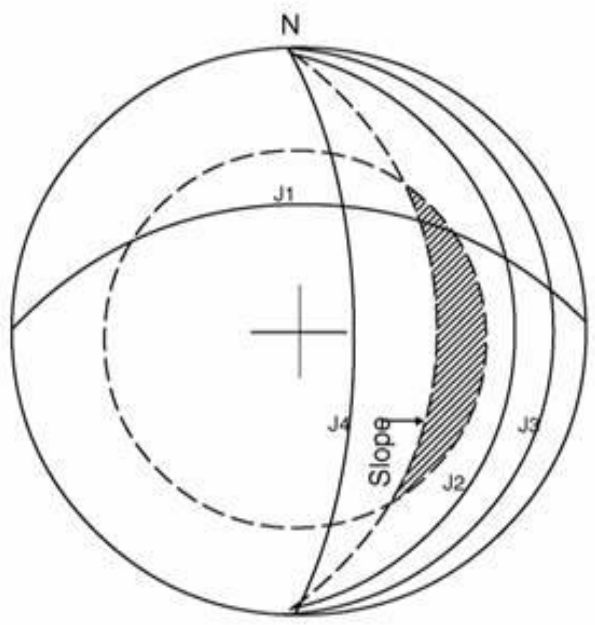

Figure 3: Stereo plot of four major sets of joints and their relationship between general hill slopes and the angle of internal friction of the rock.

at the interface of the saprolite and crystalline rock due to continuous rain. Sufficient water was not drained off and caused pore pressure that acted as a buoyant force and lifted the overlying rocks. Slumping resulted from the continued effect of ground water activity and relatively weak cohesive property of the poorly lateritised rocks. Under normal dry conditions, the profile had a factor of safety value marginally greater than one and was considered to be at the geotechnical threshold. Unscientific landuse practices followed in the localities caused the disaster. Improper slope cut cliff, toe cutting and non provision of surface drainage are the causative factors for the failure. During rain storms, the rate of infiltration in the unsaturated zone of the soil exceeds the rate of deep percolations in the rock below the soil. Even though some water moves as seepage parallel to the slope, a temporary water table develops and increases the water head. As a consequence of the rise, the piezometric head increased, the pore water pressure increased and the shearing resistance decreased, causing failure.

\subsection{Amboori, debris flow (2001)}

The Amboori debris flow is the worst landslide disaster of Kerala, which buried 38 people and destroyed three houses completely. The failed slope is located in the Kurishumala hills and has a gradient of $36^{\circ}$. The maximum elevation is $355 \mathrm{~m}$ from MSL. The head of the scar of the debris flow starts from a height of $244 \mathrm{~m}$ and extends down to Amboori-Kumbichal road, which is located at a height of $160 \mathrm{~m}$. The scar of the debris flow exposed fresh crystalline rocks. The debris consisted of boulders and weathered rocks. Biotite gneiss and quartzo feldspathic gneiss are the parent rock types of the area. They are well jointed. The vertical 
profile consists of laterite, lithomarge, weathered rock and crystalline rock from top to bottom. The thickness of the overburden and laterite together varies from 1 to $8 \mathrm{~m}$. The laterite is red coloured with patches of clay minerals. White coloured lithomarges with shades of pink occur along the interface of the weathered rock and laterite. The friction angle of the weakest material (lithomarge) is as low as $14^{\circ}$. The entire hill, except the rocky top, is under cultivation. The slope is cultivated with rubber. Contour bunds were constructed across the slope to retain water. The natural hollows were obstructed by the bunds cut in laterite. The hill slope has scattered houses and settlements situated at the base of the slope. Excess rain water infiltrated through the upper lateritic zone with a void index 0.48 and eventually water collected in the pore spaces of the lithomarge, which has a relatively low void index of 0.19 . The laterite and lithomarge were over saturated with water, the weight increased and consequently the force exerted downward on the failure plane with a trend $\mathrm{N} 40^{\circ}$ $\mathrm{W}-\mathrm{S} 40^{\circ} \mathrm{E}$ and dip in conformity with the slope. The water accumulated built up pore pressure and exceeded shear strength along the contact of the fresh crystalline rock and overburden and this resulted in planar failure.

\section{Rainfall-the triggering force}

Guzzetti et al. [10] suggested that for rainfall induced landslides, a threshold may define the rainfall, soil moisture, or hydrological conditions that when reached or exceeded are likely to trigger landslides. Dai et al. [11] have proposed a different type of empirical rainfall threshold for the possible initiation of landslides. The relationship between the amount of rainfall and ten disasters is critically examined here. The amount of rainfall on the day of occurrence of slope failures and five days prior to the failures is listed in the table 2 . Since the onset of every monsoon, three or four episodes occur during which copious rainfall occurs continuously for a couple of days. All the slope failures are associated with one such episode falling within the monsoon period (fig. 4). It is found that the locations experienced a prolonged and intense rainfall spell over the five days period, with a minimum cumulative value of $134 \mathrm{~mm}$ and a maximum value of $830 \mathrm{~mm}$ (table 2). We encountered only a single event, at Nellikkachal, where slope failure occurred with relatively less rain on the day of occurrence. However, the cumulative rainfall for the previous five days is as high as $342 \mathrm{~mm}$. It is evident that it is not the influence of the rainfall on that day alone, but the amount of rainfall during the last few days is highly influential in triggering slope instability. The variation in threshold value may be attributed to

the local characteristics of the location, such as lithology, hydraulic conductivity, soil depth, slope and vegetation.

\section{Conclusion}

Based on the analysis of various slope failures that occurred along the hill ranges of the Kerala Western Ghats, it is evident that the structural features, lithology, 
Table 2: $\quad$ The amount of rainfall on the day of occurrence of slope failures and five days prior to the failures.

\begin{tabular}{|c|c|c|c|}
\hline Sl No & Locations & $\begin{array}{c}\text { Rainfall on the } \\
\text { day of the slide } \\
(\mathrm{mm})\end{array}$ & $\begin{array}{c}\text { Rainfall 5 } \\
\text { days prior to } \\
\text { the slide (mm) }\end{array}$ \\
\hline 1 & Nellikachal & 19.2 & 342 \\
\hline 2 & Pullupara & 380 & 830 \\
\hline 3 & Govt College, Munnar & 8 & 93 \\
\hline 4 & Anthoniar Colony, & 8 & 230.8 \\
\hline 5 & Aunnar & 120 & 218 \\
\hline 6 & Chekkunnu Mala & 85 & 298 \\
\hline 7 & Pasukkadavu & 54 & 134 \\
\hline 8 & Amboori & 85 & 390 \\
\hline 9 & Vadavathoor & 60 & \\
\hline 10 & Ninnumullipara & 119 & \\
\hline
\end{tabular}

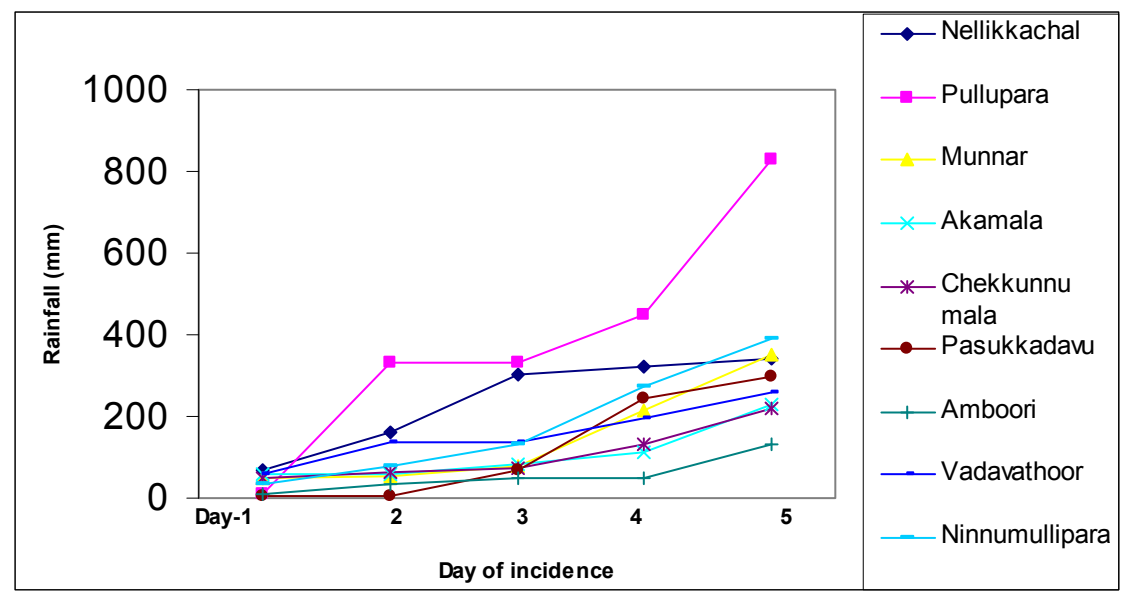

Figure 4: Rainfall cumulative graph showing the relationship between rainfall and the slope failure. The event occurred on the fifth day. 
slope condition, anthropogenic and climate play a key role in slope failures. Three major types of slope failures are debris flow, slump and landslides, the last of which are more common. Almost all mass movement occurs during monsoons, indicating that the main triggering mechanism is pore pressure variation as a result of the cumulative effect of prolonged and high intensity rainfall for a few days. The slope is made more conducive for slope failures by human intervention, such as deforestation, cultivation of crops with shallow roots, terracing, toe cutting and the blockage of natural drainage. In all cases, the causes are site specific. It is evident that it is not the influence of the rainfall on that day alone, but the amount of rainfall during the last few days is highly influential in triggering slope instability. The variation in threshold value may be attributed to the local characteristics of the location, such as lithology, hydraulic conductivity, soil depth, slope and vegetation.

\section{Acknowledgement}

The authors are thankful to KSCSTE, the Government of Kerala, for extending financial assistance to carry out the major research project on slope instability in parts of the Kerala Western Ghats.

\section{References}

[1] Census of India Population distribution, percentage decadel growth rate, sex ratio and population density of Kerala, 2001, Government of Kerala. http://kerala.gov.in/statistical/vitalstatstics/1.02.pdf, 2001.

[2] Kumar B. M., Land use in Kerala: changing scenarios and shifting paradigms. Journal of tropical agriculture, 42 (1-2), pp. 1-12, 2005.

[3] Sekhar L. Kuriakose, G Sankar, \& C Muraleedharan., History of landslide susceptibility and a chorology of landslide prone areas in the Western Ghats of Kerala , India. Environmental Geology, 57, pp. 1553-1568, 2009.

[4] Thampi P K, Mathai J \& Sankar G., A regional evolution of landslide prone areas in Western Ghats of Kerala. In: Abstracts of the national seminar on landslide in Western Ghats, Center for Earth Science Studies, Government of Kerala, 1995.

[5] Sreekumar. S., Geotechnical and petrological studies of slopes along the Kottayam-Kumili road, Kerala state, India. PhD thesis (unpublished), submitted to the University of Kerala, Trivandrum, India, 1998.

[6] Simoni, A., Berti, M., Generali, M., Elmi, C \& Ghirotti, M., Preliminary result from pore pressure monitoring on an unstable clay slope. Engineering Geology, Vol 73, pp. 117-128, 2004.

[7] Melelli, L. Taramelli, A., An example of debris flows hazard modeling using GIS. Natural Hazard and Earth System Sciences, Vol. 4, No. 3, pp. 347-358, 2004. Thiruvananthapuram district, Kerala. Journal Geological Society of India, Vol. 66, pp. 223-208, 2008.

[8] Hoek E \& Bray J.W., Rock slope engineering. The institution of mining and metallurgy, London 358, pp. 320-358, 1981. 
[9] Fellenius. W., Calculation of stability of earth dams, Transaction of the second international congress on large dams, Washington D C, 4, pp. 445465, 1936.

[10] Guzzetti, F., Peruccacci, S., Rossi, M \& Stark, C.P., Rainfall Threshold For The Initiation Of Land Slides In Central And South Europe. Meteorology and Atmospheric Physics, 98: pp. 239-267, 2007.

[11] Dai F.C, Lee C F \& S J Wang., Characterisation of rainfall induced landslides, International Journal of Remote Sensing, Vol 24, Issue 23, pp. 4817-4834, 2003. 